\title{
Psychiatric Aspects of Spinal Cord Injury
}

\author{
A. J. LASICH
}

\section{SUMMARY}

The nature of behavioural and emotional reactions displayed by persons with spinal cord injury are described and the value of psychiatric involvement in the routine management is discussed. The importance of emotional care of spinal cord injured patients is emphasized with reference to certain general principles. The psychiatrist should be accessible to both staff and patients for ventilation of feelings.

Spinal cord injury (SCI) represents one of the most devastating disabilities known to man. The severity of the lesion results in the total disruption of the victim's life and may subject him to permanent suffering and institutionalization.

By far the majority of SCI patients are male and usually younger than 40 years of age. Typically the patient is a fit healthy young man who has been accustomed to physical activity. Approximately half of the $\mathrm{SCl}$ cases are paraplegics and the other half quadriplegics. Most injuries are caused by motor vehicle accidents, while falls, gunshot and stab wounds account for a large proportion of the remainder. The mortality rate amongst these cases has fallen in recent years with improved nursing techniques.

\section{ROLE OF THE PSYCHIATRIST}

It is felt by some practitioners that the psychiatrist should be involved in an initial psychiatric evaluation soon after admission, i.e. during the acute stage of the illness.

The aim of this early contact is to assess a) the coping strategies used by the patients in dealing with past stresses and b) the need if any, for further psychiatric intervention. This initial interview helps to

A. J. Lasich, M.B. B.Ch., D.P.M., FF. Psych. Senior Specialist/Senior Lecturer, Dept of Psychiatry, Faculty of Medicine, University of Natal, Durban 4001

\section{OPSOMMING}

Die aard van die gedrags- en emosionele reaksies wat vertoon word deur persone met rugmurgbesering word beskryf, en die waarde van psigiatriese inwikkeling in die roetine hantering word bespreek. Die belangrikheid van die emosionele sorg van rugmurgbeseerde pasiënte word beklemtoon met verwysing tot sekere algemene beginsels. Die psigiater behoort beskikbaar te wees vir die ventilasie van gemoedere deur beide personeel en pasiënte.

establish the psychiatrist as a member of the team and not regarded as a stranger should the patient require assistance at a later stage of the illness. Important aspects of the patient's history which need to be investigated are his work history, social relationships, information concerning pastimes, interests and habits and lastly, whether he has knowledge of someone else with SCI.,

Apart from the occasions when a psychiatrist may be asked to attend to a patient with symptoms of a psychiatric disorder, he should when possible also be available to conduct groups for staff. It is important to remember that the individuals (including enrolled nursing assistants) who have the most contact with the patient have the greatest impact on his adjustment.

\section{STAFF GROUPS}

1. Factors that make group work necessary are:

a) Constant exposure to severely disabled people is an emotionally depleting experience and can challenge the staff member's sense of psychological well being.

b) The hierarchical structure of the hospital organization runs on quasi-military lines in which resentments flow down the command chain.

c) Prolonged patient contact which often results in positive and negative feelings as experienced in any long term relationship.

2. Function of Staff Groups

a) Group work allows for sharing and mutual support.

b) Venting of resentments or ambivalent feelings which help to reduce pressure that can influence patientstaff interactions. 
c) Benefit of peer feedback and psychiatric input both of which can give perspective to the distortions that arise so easily in this work. ${ }^{2}$

\section{PROBLEMS THAT MAY BE ENCOUNTERED AND REQUIRE ATTENTION}

1. Many of the psychological reactions which are expected to occur in the patient with $\mathrm{SCl}$ are regarded as normal:

a) In the acute phase patients may develop phantom sensations; they may feel as though their extremities are lying in impossible positions. The traumatic effort of spinal cord injuries often causes extreme fear e.g. of dying, being alone or surgery. Feelings such as frustration, anxiety, anger and disappointment tend to be felt more intensely by the $\mathrm{SCl}$ patient, as are issues of identity, meaning, vocation and sexuality. Frequent reassurance, asking about fears, communication by touch and instilling confidence will help to alleviate the patient's distress.

b) In the later stages one may encounter patients who are demanding, autocratic and manipulative. While the behaviour may be maladaptive, the need it seeks to fulfil may be adaptive, i.e. to obtain a sense of mastery or control over the environment.

A patient who is manipulative and verbally abusive can prove particularly difficult to manage.

Efforts to understand the adaptive and healthy need being met by these patient behaviours will permit the staff to address the need rather than be distracted by the acting out behaviour. Manipulative patients can disrupt the entire staff by placing one nurse against another. Angry, upset staff do not provide good care and finding other avenues of control, e.g. negotiating with the patient times of Occupational Therapy, Physiotherapy, etc. will be helpful.

\section{Specific psychiatric disorders}

The patient may present with a functional psychotic disorder such as Schizophrenia, Brief Reactive Psychosis or Paranoid Disorder or an organic brain syndrome, e.g. delirium, hallucinosis. It is possible for a personality disorder to become manifest under the conditions of severe disabling illness. Less behaviourally disruptive illnesses such as Depression (Major or Minor) Anxiety States/Disorders may also occur. It is important to remember that many of the psychotropic drugs used to treat psychotic conditions and depressive states possess anticholinergic and hypotensive effects and that these effects are enhanced as a result of the spinal cord injury particularly in the quadriplegic patient. Anxiolytic agents are useful because of their muscle relaxing properties and can be used to manage anxiety with little risk. ${ }^{2}$

Some patients require psychotherapy which is necessary to deal with psychological symptoms of a subjectively distressing nature (acute or chronic) and which require more specific techniques of management.

\section{GENERAL PSYCHOLOGICAL PRINCIPLES OF CARE}

The tragedy in hospitals is that the environment assumes an impersonal quality.

1. The person with SCI has dignity, value and importance. One should recognize that nothing about the essential value and worthwhileness of the person has changed as a result of the injury.

2. A detailed explanation of what is being done and why as well as the constant presence and reassurance of the treatment team is required to secure the emotional support of SCI patients. Reassurance and support of this nature should also extend to the patient's immediate family. It is necessary too, that the family develop some insight into the anatomy and physiology of spinal cord injury.

3. Staff should make it possible for the patient with $\mathrm{SCl}$ to experience and enjoy favourite activities.

4. Staff should avoid talking "about", "over", or "for" the patient as though he were not there or unable to express himself. This advice should extend to the family as well. The use of labels should be avoided and the staff should communicate respect by announcing their presence before entering the ward. ${ }^{3}$

\section{CONCLUSION}

Spinal cord injury is one of the causes of severe disability usually occurring in the very early years of adulthood. The person abruptly becomes seriously disabled and handicapped with the extent of paralytic involvement dependent on the level of the lesion. The medical problems are multifaceted and frequently difficult to solve. Apart from the medical complications which result, severe behavioural and adjustment problems occur.

The patient as a result of injury is reduced to economic dependency and varying degrees of physical dependency. The attitude of the staff which is critical to the patient's rehabilitation must be supportive without unrealistic goal setting. Personal reactions such as hostility to the difficult patient must be avoided and an atmosphere of calm, firm commitment must be maintained.

The approach to the care of such patients has to be comprehensive bearing in mind that the needs of the patient and the family require much more than treatment of medical problems.

\section{References}

1. Fraser A. The Psychiatrist in the Spinal Unit. Aust $N Z J$ of Psychiatry 1981; 16: 246-250.

2. Stewart Thomas D. Spinal Cord Injury: A Role for the Psychiatrist. Am J Psychiatry 1977; 134: 538-54I.

3. Brackett TU, Condon N, Kindelnan KM, Bassett $L$. The Emotional Care of a Person with a Spinal Cord Injury. Brief Report. JAMA 1984; 252: 793-795. 